\title{
EFFECTS OF PALM OIL PRODUCTS ON GROWTH PERFORMANCE, BODY COMPOSITION AND FATTY ACID PROFILE OF JUVENILE MALAYSIAN MAHSEER (Tor tambroides)
}

\author{
BAMI, M L*; KAMARUDIN, M S**; SAAD, C R*;ARSHAD, A* and EBRAHIMI, M $^{*}$
}

\begin{abstract}
This study was performed to investigate the effects of different types of palm oil on the survival, growth performance, body indices, lean percentage, body composition and fatty acid profile of juvenile Malaysian mahseer, Tor tambroides. Four extruded diets containing 5\% crude palm oil (CPO), refined, bleached, deodorised palm oil (RBDPO), RBD palm olein (RBDPOo) and RBD palm stearin (RBDPOs) were prepared. Triplicate groups of $\mathrm{T}$. tambroides juveniles $(1.65 \pm 0.6 \mathrm{~g})$ were stocked in 60 litres aquaria at 20 fish per aquarium and fed the diets for 12 weeks. Fish fed CPO and RBDPOs diet showed the best feed conversion ratio (FCR), while the lowest viscero-somatic index (VSI) was observed in juveniles fed $R B D P O o$ and $R B D P O$ s. A significantly higher $(P<0.05)$ protein and gross energy retention were observed in juveniles fed RBDPOs compared to those fed RBDPO. The highest muscular retention of $n-3$ and $n-6$ long-chain polyunsaturated fatty acids ( $n-3$ and $n-6$ LC-PUFA) was observed in juveniles fed CPO diet. In addition to giving a higher PUFA ratio in mahseer muscle than other palm oil products, $C P O$ was the most cost effective palm oil type and was recommended as the lipid source in the diet of T. tambroides juvenile.
\end{abstract}

Keywords: Tor tambroides, crude palm oil, RBD palm oil, palm olein, palm stearin.

Date received: 3 April 2016; Sent for revision: 20 August 2016; Received in final form: 13 June 2017; Accepted: 28 July 2017.

\section{INTRODUCTION}

One of the most valuable cyprinid fish in the freshwater aquaculture industry is mahseer (Tor spp.). Mahseers are found throughout South-east Asia and the Himalayas. Of 30 Tor species identified, three species are found in Malaysia including the Malaysian mahseer (Tor tambroides Bleeker) (Esa

* Department of Aquaculture, Faculty of Agriculture, Universiti Putra Malaysia, 43400 UPM Serdang, Selangor, Malaysia.

** Institute of Halal Product Research, Universiti Putra Malaysia, 43400 UPM Serdang, Selangor, Malaysia.

E-mail: msalleh@upm.edu.my

* Department of Veterinary Preclinical Sciences, Faculty of Veterinary Medicine, Universiti Putra Malaysia, 43400 UPM Serdang, Selangor, Malaysia. et al., 2007; Ng, 2004). In Malaysia, T. tambroides is considered as one of the most expensive and substantial food and sport fish (Esa et al., 2007) and ornamental fish $(\mathrm{Ng}, 2004)$. The natural stock of this species has undergone a rapid decrease; in recent years (DOF, 2012; 2013; 2014; 2015; 2016; Ingram et al., 2007). The effort to breed and culture this fish has been on-going since 2005 (Ingram et al., 2005) to meet its growing demand. Feeding Malaysian mahseer with an appropriate diet which meets all or most of its nutritional requirements is critically important for the commercial aquaculture of this species. Studies on its nutrition have been conducted by several researchers in recent years.

Various fish species need essential fatty acids (EFA) including 18 carbon chain length polyunsaturated fatty acid ( $\mathrm{C}_{18}$ PUFA) and long- 
chain polyunsaturated fatty acids (LC-PUFA) containing 20 and 22 carbon chain lengths for their growth and health (Smith et al., 2004). Almost all freshwater fish, including $T$. tambroides, can synthesise LC-PUFA from $C_{18}$ PUFA (Turchini et al., 2006). Fish achieve their own EFA from various lipid sources in their diet. Moreover, n-3 LC-PUFA have lots of health beneficial effects on human as a fish consumer (Moreira et al., 2001). Therefore, it is essential to feed the fish with a diet that promotes the high maintenance of these fatty acids in its muscles.

One of the most used ingredients in the aquafeed formulation is fish oil that provides EFA as well as dietary energy $(\mathrm{Ng}, 2002)$. Such marineorigin resources are decreasing as a result of the continuously growing world population along with the rapid growth of the aquaculture industry. Much efforts have been made to find suitable substitutes for these ingredients. Most of the fish oils are produced in the temperate regions and therefore are generally expensive when made available in tropical countries $(\mathrm{Ng}, 2002)$. Palm oil is one of the potential fish oil substitutes to be incorporated in aquafeed. Palm oil is the top produced vegetable oil worldwide (FAO, 2015). It is also one of the lowest priced vegetable oils in the global market. Moreover, freshwater teleosts, including $T$. tambroides, are naturally able to produce LC-PUFA from $\mathrm{C}_{18}$ PUFA (Kamarudin et al., 2012; Ruyter et al., 2006; Tan et al., 2009; Turchini et al., 2006). Thus, they are most likely to require $\mathrm{C}_{18}$ PUFA that are highly available in vegetable oils, but not so much $C_{20}$ and $C_{22}$ LC-PUFA which are highly concentrated in fish oil. Palm oil, having high 16:0 and 18:1n-9 concentrations that are preferred over PUFA for mitochondrial $\beta$-oxidation (Lim et al., 2001), could be considered as a potential replacement as well as an energy source for fish (Moreira et al., 2001; Özogul et al., 2007).

When the mesocarp of the oil palm (Elaeis guineensis) fruit is pressed, crude palm oil (CPO) is extracted. Palm oil and its products after being refined have lots of uses around the world (Pantzaris, 1997). Many researchers have made attempts to use palm oil in fish diets since the mid-1990s. Viegas and Contreras (1994) found that a higher dietary inclusion of CPO gives a more desirable length gain and protein efficiency ratio in tambaqui (Colossoma macropomum) fingerlings compared to the dietary deodorised distillate of soyabean oil. Dietary palm oil gave better growth in African catfish, Heterobranchus longifilis, fry compared to dietary peanut, cottonseed, coconut or cod liver oil. Cod liver oil gives the lowest growth to the African catfish (Legendre et al., 1995). Al-Owafeir and Belal (1996) found that Nile tilapia (Oreochromis niloticus) can utilise palm oil as efficiently as soyabean oil in the diet. $\mathrm{Ng}$ et al. (2003) demonstrated that African catfish (Clarias gariepinus) and possibly other species of tropical catfish are able to use the palm oil commercial products with desirable feed utilisation efficiency and growth. Other researchers have also successfully utilised palm oil in the diet of different fish species (Babalola and Apata, 2012; Ng and Wang, 2011; Yu-Zhe et al., 2012; Bell et al., 2002). There have been very few studies on the use of palm oil in T. tambroides diet. Kamarudin et al. (2012) replaced fish oil with sunflower oil, linseed oil, and palm oil in the diet of T. tambroides juveniles and noted that the highest weight gain and visceral weight are achieved using refined palm oil. Moreover, those fed 50\% palm oil and 50\% fish oil in their diet contain as much liver docosahexaenoic acid (DHA, 22:6n-3) level as juveniles fed solely on fish oil diet. Ramezani-Fard et al. (2012b) compared the effects of different dietary saturated fatty acid (SFA) and n-3 PUFA contents on the growth performance and fatty acid composition (especially n-3 PUFA) of Malaysian mahseer. These researchers found that a diet containing high SFA and low n-3 PUFA (palm oil as the oil source) results in the best growth performance and fatty acid composition in T. tambroides. Unfortunately, no research on using palm oil for other Tor species has been reported.

Currently, there are four main types of palm oil in the market. $\mathrm{CPO}$ has a deep orange-red colour due to its high carotenoid content (Nesaretnam and Muhammad, 1993). This type of palm oil is also a rich source of vitamin E (Ng et al., 2003). During refining, the heat deployed destroys the carotenoids while oil impurities are removed to produce the refined, bleached, deodorised palm oil (RBDPO) with the desired colour (Young, 1987). The thermomechanical RBDPO fractionation leads to RBD palm olein (RBDPOo) production. This type of palm oil has a tremendous use as cooking oil. RBDPOs is also produced from the RBDPO fractionation as a solid type of palm oil with major use in margarines and shortenings $(\mathrm{Ng}, 2002)$. No studies were found on the use of different main palm oil types in fish feeds and comparing their effects on different fish species. Using palm oil in aquafeeds could be cost-effective particularly for tropical countries. This study was carried out to investigate the effects of these four palm oil products on the growth performance, body composition, and fatty acid profile of $T$. tambroides juveniles.

\section{MATERIALS AND METHODS}

\section{Diet Preparation}

T. tambroides optimally requires $5 \%$ dietary oil (Ramezani-Fard et al., 2012a). Four isocaloric $\left(4000 \mathrm{kcal} \mathrm{kg}^{-1}\right)$, and isonitrogenous (40\% protein) diets containing 5\% CPO, RBDPO, RBDPOo and RBDPOs were prepared (Table 1). Table 2 presents the 
TABLE 1. FEED, CHEMICAL AND FATTY ACID COMPOSITIONS OF THE EXPERIMENTAL DIETS

\begin{tabular}{|c|c|c|c|c|}
\hline \multirow[b]{2}{*}{ Ingredient ( $\%$ as fed basis) } & \multicolumn{4}{|c|}{ Experimental diet } \\
\hline & СРО & RBDPO & RBDPOo & RBDPOs \\
\hline Fishmeal $^{a}$ & 35.75 & 35.75 & 35.75 & 35.75 \\
\hline Soyabean meal & 37.81 & 37.81 & 37.81 & 37.81 \\
\hline Tapioca starch & 19.44 & 19.44 & 19.44 & 19.44 \\
\hline $\mathrm{CPO}^{\mathrm{b}}$ & 5.00 & - & - & - \\
\hline $\mathrm{RBDPO}^{\mathrm{c}}$ & - & 5.00 & - & - \\
\hline RBDPOo $^{d}$ & - & - & 5.00 & - \\
\hline RBDPOs $^{\mathrm{e}}$ & & & & 5.00 \\
\hline Vitamin premix ${ }^{\mathrm{f}}$ & 1.00 & 1.00 & 1.00 & 1.00 \\
\hline Mineral premix ${ }^{g}$ & 1.00 & 1.00 & 1.00 & 1.00 \\
\hline \multicolumn{5}{|c|}{ Proximate composition (\% as a fed basis) } \\
\hline Crude protein & 40 & 40 & 40 & 40 \\
\hline Crude lipid & 7.8 & 7.7 & 7.9 & 8.0 \\
\hline Ash & 11.9 & 11.9 & 11.9 & 11.9 \\
\hline Carbohydrates $^{\text {h }}$ & 29.7 & 29.9 & 29.6 & 29.5 \\
\hline Gross energy $\left(\mathrm{kcal} \mathrm{kg}^{-1}\right)$ & 4117.5 & 4078.0 & 4134.8 & 4106.4 \\
\hline Dry matter & 89.4 & 89.5 & 89.4 & 89.4 \\
\hline \multicolumn{5}{|c|}{ Fatty acid composition (\% of total total fatty acids) } \\
\hline $14: 0$ & 2.78 & 2.64 & 2.58 & 2.53 \\
\hline $16: 0$ & 41.15 & 41.77 & 40.65 & 55.02 \\
\hline $16: 1 \mathrm{n}-7$ & 2.25 & 2.18 & 2.31 & 2.29 \\
\hline $18: 0$ & 6.52 & 6.52 & 6.94 & 6.50 \\
\hline $18: 1 n-9$ & 36.54 & 36.52 & 37.00 & 26.71 \\
\hline $18: 2 n-6$ & 7.87 & 7.56 & 7.71 & 4.46 \\
\hline $18: 3 n-3$ & 0.63 & 0.40 & 0.41 & 0.27 \\
\hline $20: 4 n-6$ & 0.64 & 0.65 & 0.61 & 0.60 \\
\hline $20: 5 n-3$ & 0.48 & 0.47 & 0.49 & 0.50 \\
\hline $22: 5 n-3$ & 0.51 & 0.46 & 0.49 & 0.43 \\
\hline $22: 6 n-3$ & 0.83 & 0.83 & 0.82 & 0.80 \\
\hline$\Sigma \mathrm{SFA}^{\mathrm{i}}$ & 50.45 & 50.93 & 50.17 & 64.06 \\
\hline$\Sigma \mathrm{UFA}^{\mathrm{j}}$ & 49.55 & 49.08 & 49.83 & 35.95 \\
\hline$\Sigma$ MUFA $^{\mathrm{k}}$ & 38.79 & 38.71 & 39.31 & 28.89 \\
\hline$\sum$ n-3 PUFA ${ }^{1}$ & 2.45 & 2.16 & 2.20 & 2.00 \\
\hline$\sum \mathrm{n}-6 \mathrm{PUFA}^{\mathrm{m}}$ & 8.32 & 8.21 & 8.31 & 5.06 \\
\hline$n-6 / n-3$ & 3.40 & 3.80 & 3.77 & 2.53 \\
\hline$n-3 / n-6$ & 0.29 & 0.26 & 0.27 & 0.40 \\
\hline UFA/SFA & 0.98 & 0.96 & 0.99 & 0.56 \\
\hline PUFA/SFA & 0.21 & 0.20 & 0.21 & 0.11 \\
\hline
\end{tabular}

Note: ${ }^{\mathrm{a}}$ Fishmeal-Malaysian fishmeal (59.6\% crude protein), ${ }^{\mathrm{b}} \mathrm{CPO}$ - crude palm oil supplied by MPOB, ${ }^{\mathrm{c}} \mathrm{RBDPO}$ - refined, bleached and deodorised palm oil supplied by MPOB, ${ }^{\mathrm{d}} \mathrm{RBDPOo}$ - refined, bleached and deodorised palm olein supplied by MPOB, ${ }^{\mathrm{e}} \mathrm{RBDPOs}$ - refined, bleached and deodorised palm stearin supplied by MPOB, ${ }^{\mathrm{f}}$ Vitamin premix - ( $\mathrm{g} \mathrm{kg}{ }^{-1}$ premix): ascorbic acid, 45; myo-inositol, 5; choline chloride, 75; niacin, 4.5; riboflavin, 1; pyridoxine, 1; thiamin mononitrate, 0.9; Ca-pantothenate, 3; retinyl acetate, 0.6; cholecalciferol, 0.08; vitamin $\mathrm{K}$ menadione, 1.7; $\alpha$-tocopheryl acetate $\left(500 \mathrm{IU} \mathrm{g}^{-1}\right)$, 8; biotin, 0.02; folic acid, 0.1; vitamin B12, 0.001; cellulose, 845.1, ${ }^{\mathrm{g}} \mathrm{Mineral}$ premix - (g kg-1 premix): KCL, 90; KI, 0.04; $\mathrm{CaHPO} .2 \mathrm{H}_{2} \mathrm{O}, 500 ; \mathrm{NaCl}, 40 ; \mathrm{CuSO}_{4} .5 \mathrm{H}_{2} \mathrm{O}, 3 ; \mathrm{ZnSO}_{4} .7 \mathrm{H}_{2} \mathrm{O}, 4 ; \mathrm{CoSO}_{4}, 0.02 ; \mathrm{FeSO}_{4} .7 \mathrm{H}_{2} \mathrm{O}, 20$; $\mathrm{MnSO}_{4} \cdot \mathrm{H}_{2} \mathrm{O}, 3 ; \mathrm{CaCO}_{3}, 215 ; \mathrm{MgOH}, 124 ; \mathrm{Na}_{2} \mathrm{SeO}_{3}, 0.03 ; \mathrm{NaF}, 1,{ }^{\mathrm{h}}$ Carbohydrate = dry matter - [protein + lipid + ash], ${ }^{\text {, SFA }}$ - saturated fatty acids (sum of 14:0+16:0+18:0; 20:0 and 22:0 were not detected), j UFA - unsaturated fatty acids, ${ }^{\mathrm{k}}$ MUFA - monounsaturated fatty acids (sum of 16:1n-7+18:1n-9; 20:1n-9, 22:1n-9, 24:1n-9 and 22:1n-11 were not detected), ${ }^{1} \mathrm{n}-3$ PUFA - the $\mathrm{n}-3$ polyunsaturated fatty acids (sum of 18:3n-3+20:5n-3+22:5n-3+22:6n-3; 20:4n-3, 24:5n-3 and 24:6n-3 were not detected), ${ }^{m} n-6$ PUFA - the $n-6$ polyunsaturated fatty acids (sum of $18: 2 n-6+20: 4 n-6 ; 20: 2 n-6,20: 3 n-6$ and 22:5n-6 were not detected).

fatty acid compositions of different lipid sources. A kitchen mixer was used to mix the dry ingredients. A homogeneous mixture was produced after adding distilled water and test oils. A single screw laboratory-scale extruder (Brabender KE-19) was used to extrude the moist mixture through a $2-\mathrm{mm}$ die. The pellets were oven-dried at $45^{\circ} \mathrm{C}$ for $4 \mathrm{hr}$, cooled to the room temperature, bagged and stored with dehumidifying agents till used.

\section{Rearing and Sampling}

T. tambroides juveniles (mean initial body weight $=1.65 \pm 0.6 \mathrm{~g}$ ) were purchased from a local supplier 
TABLE 2. FATTY ACID COMPOSITION (\% of total fatty acids) OF DIFFERENT LIPID SOURCES

\begin{tabular}{|c|c|c|c|c|c|c|}
\hline \multirow[b]{2}{*}{ Fatty acid } & \multicolumn{6}{|c|}{ Type of the lipid source } \\
\hline & Fishmeal $^{a}$ & Soyabean meal ${ }^{\mathrm{b}}$ & $\mathrm{CPO}^{c}$ & $\mathrm{RBDPO}^{\mathrm{d}}$ & $\mathrm{RBDPOo}^{\mathrm{e}}$ & RBDPOs $^{f}$ \\
\hline $14: 0$ & 4.87 & 0.00 & 1.53 & 1.44 & 1.00 & 0.00 \\
\hline $16: 0$ & 31.77 & 19.51 & 43.94 & 44.93 & 41.03 & 63.94 \\
\hline $16: 1 n-7$ & 5.37 & 0.00 & 0.00 & 0.00 & 0.00 & 0.00 \\
\hline $18: 0$ & 11.27 & 4.69 & 4.17 & 3.80 & 3.40 & 4.15 \\
\hline $18: 1 n-9$ & 19.72 & 17.07 & 39.98 & 39.88 & 43.85 & 26.46 \\
\hline $18: 2 n-6$ & 2.53 & 50.85 & 10.18 & 9.80 & 10.57 & 5.35 \\
\hline $18: 3 n-3$ & 0.93 & 7.90 & 0.21 & 0.17 & 0.17 & 0.10 \\
\hline $20: 4 n-6$ & 3.93 & 0.00 & 0.00 & 0.00 & 0.00 & 0.00 \\
\hline $20: 5 n-3$ & 5.51 & 0.00 & 0.00 & 0.00 & 0.00 & 0.00 \\
\hline $22: 5 n-3$ & 2.40 & 0.00 & 0.00 & 0.00 & 0.00 & 0.00 \\
\hline $22: 6 n-3$ & 11.73 & 0.00 & 0.00 & 0.00 & 0.00 & 0.00 \\
\hline$\Sigma \mathrm{SFA}^{\mathrm{h}}$ & 47.90 & 24.19 & 49.63 & 50.16 & 45.43 & 68.10 \\
\hline$\Sigma \mathrm{UFA}^{\mathrm{i}}$ & 52.10 & 75.81 & 50.37 & 49.84 & 54.58 & 31.91 \\
\hline$\Sigma$ MUFA $^{j}$ & 25.08 & 17.07 & 39.98 & 39.88 & 43.85 & 26.46 \\
\hline$\sum$ n-3 PUFA ${ }^{k}$ & 20.55 & 7.90 & 0.21 & 0.17 & 0.17 & 0.10 \\
\hline$\sum$ n-6 PUFA ${ }^{1}$ & 6.47 & 50.85 & 10.18 & 9.80 & 10.57 & 5.35 \\
\hline$n-6 / n-3$ & 0.32 & 6.47 & 53.01 & 45.09 & 63.88 & 54.01 \\
\hline$n-3 / n-6$ & 3.18 & 0.16 & 0.02 & 0.02 & 0.02 & 0.02 \\
\hline UFA/SFA & 1.09 & 3.17 & 1.02 & 1.00 & 1.20 & 0.47 \\
\hline PUFA/SFA & 0.57 & 2.47 & 0.21 & 0.20 & 0.24 & 0.08 \\
\hline
\end{tabular}

Note: ${ }^{a}$ Malaysian fishmeal with $7.9 \%$ lipid. ${ }^{b}$ Soyabean meal with $0.6 \%$ lipid, ${ }^{\mathrm{C}} \mathrm{CPO}$ - crude palm oil supplied by MPOB, ${ }^{\mathrm{d}} \mathrm{RBDPO}-\mathrm{refined}$,

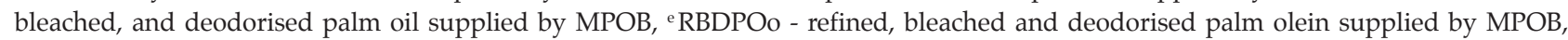
${ }^{\mathrm{f}}$ RBDPOs - refined, bleached and deodorised palm stearin supplied by MPOB, g SFA - saturated fatty acids (sum of 14:0+16:0+18:0; 20:0 and 22:0 were not detected), h ${ }^{2}$ FA - unsaturated fatty acids, ${ }^{\mathrm{i}}$ MUFA - monounsaturated fatty acids (sum of 16:1n-7+18:1n-9; 20:1n-9, 22:1n-9, 24:1n-9 and 22:1n-11 were not detected), ${ }^{j} n-3$ PUFA-the n-3 polyunsaturated fatty acids (sum of 18:3n-3+20:5n-3+22:5n-3+22:6n-3; 20:4n-3, 24:5n-3 and 24:6n-3 were not detected), ${ }^{k}$ n-6 PUFA-the n-6 polyunsaturated fatty (sum of 18:2n-6+20:4n-6; 20:2n-6, 20:3n-6 and 22:5n-6 were not detected).

and transferred to the Wet Laboratory, Department of Aquaculture, Faculty of Agriculture, Universiti Putra Malaysia, Selangor, Malaysia. The fish were initially acclimatised in a 1-t fibreglass tank for two weeks. Fish were then randomly distributed into 1260 litres rectangular-shaped glass aquaria containing 20 fish per aquarium. Each aquarium was fitted with a top bio-filter and aerated. Water quality was monitored at every three weeks. Water temperature ranged between $26.4^{\circ} \mathrm{C}$ and $29.8^{\circ} \mathrm{C}$ and $\mathrm{pH}$ was found between 6.5 and 7.4. The ammonia $\left(\mathrm{NH}_{3}{ }^{+}\right)$level was always below $0.2 \mathrm{mg}$ litre-1.

The fish were fed twice per day (0900 and 1600 $\mathrm{hr}$ ) close to the visual satiety during the trial. The feeding trial was conducted for 12 weeks. The fish in each aquarium were individually weighed at the start and end of the feeding trial, as well as at every three weeks. Weight gain, specific growth rate (SGR), daily feed intake (DFI) and feed conversion ratio (FCR) were estimated at the end of the experiment.

Before starting the feeding trial, 20 fish were sacrificed and individually weighed. Fifteen of them were kept at $-20^{\circ} \mathrm{C}$ for subsequent whole body composition analysis and the muscle and liver tissue of other five juveniles were removed and stored at $-80^{\circ} \mathrm{C}$ for fatty acid analysis. At the end of the experiment, the fish per treatment (five per replicate) were also sacrificed, individually weighed and dissected for the hepato-somatic index (HSI) and viscera-somatic index (VSI) estimation. The fish were starved for $24 \mathrm{hr}$ to facilitate the liver collection and VSI estimation. The dissected fish were then dressed and muscles from the area between the lateral and dorsal line were removed for the fatty acid analyses (Ahlgren et al., 1994). The liver and muscle samples were quickly stored at $-80^{\circ} \mathrm{C}$ till fatty acid analyses. Other 45 fish per treatment (15 fish per replicate) were sacrificed, weighed individually and stored at $-20^{\circ} \mathrm{C}$ for subsequent whole body composition analysis.

\section{Biochemical Analysis}

Before the biochemical analysis, the whole body of the fish were dried in the oven at $40^{\circ} \mathrm{C}$ for $48 \mathrm{hr}$ and the moisture loss was calculated. After that, the samples were ground into fine powder. The moisture contents of experimental diets were estimated by using an infrared moisture-determining balance (A\&D, AD-4715). The crude protein, crude lipid and crude fibre of experimental diets and the whole body of fish samples were determined by the Kjeldahl method (Foss KjeltecTM 8000), Soxhlet extraction (Foss SoxtecTM 8000) and hot extraction 
(Foss FibertecTM 2010) according to AOAC methods (1997), respectively. The ash content was estimated by cauterising the dry sample at $600^{\circ} \mathrm{C}$ for $4 \mathrm{hr}$, and the gross energy was measured by direct incineration in an adiabatic bomb calorimeter (Leco Co. AC-350).

Lipid from the feed, liver, and muscle was extracted using a chloroform: methanol (2:1 v:v) mixture, saponated by potassium hydroxide $(\mathrm{KOH})$ and transesterified with methanolic boron trifluoride according to AOAC Methods (1997). The separation and quantification of fatty acid methyl esters (FAME) were performed using a fused silica capillary column (Supelco SP-2330: $30 \mathrm{~m} \times 0.25 \mathrm{~mm}$, film thickness $0.20 \mu \mathrm{m}$ ) in a gas chromatograph (Agilent 7890N) equipped with a split/splitless injector and flame ionisation detector. High purity nitrogen was used as the carrier gas. The fatty acids were identified by comparison of the relative FAME peak retention time with the standards obtained from Sigma (St Louis, MO, USA) and expressed as the area percentage of FAME.

\section{Statistical Analysis}

Statistical analyses were done using SPSS 18 for Windows (SPSS Inc., Chicago, II. USA). Percentage data were arcsin-transformed prior to being analysed. Data were then evaluated by analysis of variance (ANOVA) and significant differences were determined by Duncan's Multiple Range Test. The P-value less than 0.05 was considered statistically significant and the results expressed as means \pm standard error (SE).

\section{RESULTS}

The survival, final weight, weight gain, DFI, SPG, FCR, VSI, HSI, protein efficiency ratio (PER) and lean percentage of $T$. tambroides fed different types of dietary palm oil are shown in Table 3. Oil type did not have any significant effect $(P>0.05)$ on the survival, final weight, weight gain, SGR, DFI, PER, HSI and lean percentage of T. tambroides juveniles. The best FCR was observed in fish fed RBDPOs diet, which was only significantly better $(P<0.05)$ than those fed RBPO diet. Juveniles fed RBPO diet had significantly $(\mathrm{P}<0.05)$ higher VSI than juveniles fed RBDPOo and RBDPOs diets.

The type of palm oil also did not have any significant effect $(\mathrm{P}>0.05)$ on dry matter and whole body proximate composition except for ash (Table 4). The ash content of juveniles fed RBDPS and RBDPOo diet were significantly higher $(\mathrm{P}<0.05)$ than that of fish fed CPO diet. Table 5 shows fish fed RBDPOs diet had significantly higher dietary energy and protein retention $(\mathrm{P}<0.05)$ than those fed the RBDPO diet, while dietary lipid and carbohydrate retention were not significantly affected $(P>0.05)$ by the type of palm oil. Lipid retention among the mahseer juveniles was extremely high and ranged between 175\%-248\% while an extremely low range $(2.6 \%-10.8 \%)$ was observed in the carbohydrate retention.

Table 6 shows the muscle fatty acid compositions of mahseer fed different types of palm oil. The most dominant fatty acid in the fish muscle was 18:1n-9 followed by 16:0, 18:2n-6, 18:0 and 16:1n-7. A significantly higher $(\mathrm{P}<0.05)$ total n-3 PUFA was

TABLE 3. SURVIVAL RATE, GROWTH PERFORMANCE, FEED UTILISATION EFFICIENCY AND BODY INDICES OF T. tambroides JUVENILE FED THE TEST DIETS FOR 12 WEEKS

\begin{tabular}{|c|c|c|c|c|}
\hline & \multicolumn{4}{|c|}{ Experimental diet } \\
\hline & $\mathrm{CPO}^{\mathrm{a}}$ & $\mathrm{RBDPO}^{\mathrm{b}}$ & $\mathrm{RBDPOo}^{\mathrm{c}}$ & $\mathrm{RBDPOs}^{\mathrm{d}}$ \\
\hline Survival (\%) & $100 \pm 0.00$ & $100 \pm 0.00$ & $100 \pm 0.00$ & $100 \pm 0.00$ \\
\hline Final weight (g) & $4.88 \pm 0.31$ & $4.96 \pm 0.23$ & $4.67 \pm 0.50$ & $5.16 \pm 0.28$ \\
\hline Weight gain $(\%)$ & $195.55 \pm 18.52$ & $200.61 \pm 13.98$ & $182.83 \pm 30.20$ & $212.93 \pm 16.81$ \\
\hline $\operatorname{SGR}\left(\% \mathrm{~d}^{-1}\right)^{\mathrm{e}}$ & $1.30 \pm 0.07$ & $1.32 \pm 0.06$ & $1.24 \pm 0.13$ & $1.37 \pm 0.06$ \\
\hline $\mathrm{FCR}^{\mathrm{f}}$ & $2.29 \pm 0.02^{\mathrm{AB}}$ & $2.89 \pm 0.27^{\mathrm{B}}$ & $2.50 \pm 0.20^{\mathrm{AB}}$ & $1.90 \pm 0.13^{\mathrm{A}}$ \\
\hline DFI $\left(\% \mathrm{~d}^{-1}\right)^{\mathrm{g}}$ & $2.72 \pm 0.11$ & $3.48 \pm 0.40$ & $2.79 \pm 0.08$ & $2.34 \pm 0.27$ \\
\hline $\mathrm{PER}^{\mathrm{h}}$ & $2.50 \pm 0.00$ & $2.50 \pm 0.00$ & $2.50 \pm 0.00$ & $2.50 \pm 0.00$ \\
\hline $\operatorname{HSI}(\%)^{\mathrm{i}}$ & $2.81 \pm 1.05$ & $2.39 \pm 0.13$ & $2.08 \pm 0.53$ & $1.77 \pm 0.21$ \\
\hline VSI $(\%)$ & $11.03 \pm 0.96^{\mathrm{AB}}$ & $14.05 \pm 0.70^{\mathrm{B}}$ & $9.07 \pm 1.40^{\mathrm{A}}$ & $8.10 \pm 1.27^{\mathrm{A}}$ \\
\hline Lean $(\% \text { wet weight })^{k}$ & $60.00 \pm 0.12$ & $60.00 \pm 1.25$ & $60.00 \pm 0.26$ & $60.00 \pm 1.10$ \\
\hline
\end{tabular}

Note: Mean $\pm \mathrm{SE}(\mathrm{n}=3)$; means within the same row with different uppercase letters are significantly different at $\mathrm{P}<0.05$, ${ }^{\mathrm{a}} \mathrm{CPO}$ - crude palm oil supplied by MPOB, ${ }^{b}$ RBDPO - refined, bleached, and deodorised palm oil supplied by MPOB, ${ }^{c}$ RBDPOo - refined, bleached and deodorised palm olein supplied by MPOB, ${ }^{\mathrm{d}}$ RBDPOs - refined, bleached and deodorised palm stearin supplied by MPOB, eSGR specific growth rate $=[(\ln$ final mean weight $-\ln$ initial mean weight $) /$ experimental days $] \times 100,{ }^{f} \mathrm{FCR}-$ feed conversion ratio $=$ total feed intake $(\mathrm{g}) /$ wet gain $(\mathrm{g}),{ }^{\mathrm{g}} \mathrm{DFI}$ - daily feed intake $=100 \times$ total feed intake $(\mathrm{g}) /[$ total final body weight+ total initial body weight $(\mathrm{g}) / 2$ ] $\times$ experimental days, ${ }^{\mathrm{h}}$ PER - protein efficiency ratio $=$ wet weight gain $(\mathrm{g}) /$ total protein intake $(\mathrm{g}),{ }^{\mathrm{i}} \mathrm{HSI}-\mathrm{Hepato-somatic} \mathrm{index}=100 \times$ liver weight $(\mathrm{g}) /$ body weight $(\mathrm{g}),{ }^{,}$VSI - viscero-somatic index $=100 \times$ visceral weight $(\mathrm{g}) /$ body weight $(\mathrm{g}),{ }^{\mathrm{k}}$ Lean $(\%$ wet weight $)=100$ $\times$ muscle weight $(\mathrm{g}) /$ body weight $(\mathrm{g})$. 
TABLE 4. WHOLE BODY PROXIMATE COMPOSITION (\% wet weight) OF JUVENILE T. tambroides FED THE EXPERIMENTAL DIETS FOR 12 WEEKS

\begin{tabular}{|c|c|c|c|c|c|}
\hline & \multicolumn{5}{|c|}{ Experimental diet } \\
\hline & Initial & $\mathrm{CPO}^{\mathrm{a}}$ & $\mathrm{RBDPO}^{\mathrm{b}}$ & $\mathrm{RBDPOo}^{\mathrm{c}}$ & RBDPOs $^{\mathrm{d}}$ \\
\hline Dry matter & 34.33 & $38.43 \pm 0.83$ & $38.54 \pm 0.98$ & $37.65 \pm 1.95$ & $38.70 \pm 1.09$ \\
\hline Crude protein & 14.49 & $15.81 \pm 0.49$ & $15.66 \pm 0.68$ & $16.95 \pm 1.80$ & $17.04 \pm 1.30$ \\
\hline Crude lipid & 11.12 & $18.30 \pm 3.82$ & $17.87 \pm 0.82$ & $15.77 \pm 1.38$ & $15.81 \pm 2.31$ \\
\hline Ash & 4.16 & $2.24 \pm 0.06^{\mathrm{A}}$ & $2.49 \pm 0.06^{\mathrm{AB}}$ & $2.76 \pm 0.18^{\text {В }}$ & $2.80 \pm 0.18^{\mathrm{B}}$ \\
\hline Fibre & 0.20 & $0.56 \pm 0.28$ & $0.57 \pm 0.16$ & $0.81 \pm 0.19$ & $0.79 \pm 0.10$ \\
\hline $\mathrm{NFE}^{\mathrm{e}}$ & 4.35 & $3.59 \pm 2.06$ & $1.95 \pm 0.64$ & $1.97 \pm 0.99$ & $2.26 \pm 1.70$ \\
\hline Carbohydrate & 4.55 & $4.15 \pm 2.31$ & $2.53 \pm 0.79$ & $2.77 \pm 0.83$ & $3.05 \pm 1.78$ \\
\hline Gross energy ( $\left.\mathrm{kcal} \mathrm{kg}^{-1}\right)$ & 2832.34 & $2693.15 \pm 65.56$ & $2794.48 \pm 128.83$ & $2848.85 \pm 304.02$ & $2905.39 \pm 90.25$ \\
\hline
\end{tabular}

Note: Mean \pm SE $(n=3)$; means within the same row with different uppercase letters are significantly different at $\mathrm{P}<0.05$, ${ }^{a} \mathrm{CPO}-\mathrm{crude}$ palm oil supplied by MPOB, ${ }^{b}$ RBDPO - refined, bleached, and deodorised palm oil supplied by MPOB, ${ }^{c}$ RBDPOo - refined, bleached and deodorised palm olein supplied by MPOB, ${ }^{\mathrm{d}} \mathrm{RBDPO}$ - refined, bleached and deodorised palm stearin supplied by MPOB, ${ }^{\mathrm{N}} \mathrm{NE}$ - nitrogen free extract $=$ dry matter $-($ protein + lipid + ash + fibre $)$.

TABLE 5. ESTIMATED PROTEIN, LIPID, CARBOHYDRATE AND ENERGY RETENTION (\%) OF T. tambroides JUVENILES FED THE EXPERIMENTAL DIETS FOR 12 WEEKS

\begin{tabular}{|c|c|c|c|c|}
\hline \multirow[b]{2}{*}{ Retention } & \multicolumn{4}{|c|}{ Experimental diet } \\
\hline & $\mathrm{CPO}^{\mathrm{a}}$ & $\mathrm{RBDPO}^{\mathrm{b}}$ & $\mathrm{RBDPOo}^{\mathrm{c}}$ & RBDPOs $^{d}$ \\
\hline Crude protein $(\%)^{\mathrm{e}}$ & $35.00 \pm 1.79^{\mathrm{AB}}$ & $28.50 \pm 2.49^{\mathrm{A}}$ & $35.43 \pm 10.03^{\mathrm{AB}}$ & $51.31 \pm 6.03^{\mathrm{B}}$ \\
\hline Crude lipid $(\%)^{\mathrm{f}}$ & $235.93 \pm 51.36$ & $193.11 \pm 16.75$ & $175.31 \pm 39.50$ & $248.21 \pm 32.23$ \\
\hline Carbohydrate $(\%)^{\mathrm{g}}$ & $10.88 \pm 7.07$ & $2.60 \pm 1.73$ & $3.96 \pm 2.83$ & $7.64 \pm 7.64$ \\
\hline Gross energy $(\%)^{\mathrm{h}}$ & $54.50 \pm 6.79^{\mathrm{AB}}$ & $47.56 \pm 2.99^{\mathrm{A}}$ & $53.15 \pm 15.08^{\mathrm{AB}}$ & $80.04 \pm 2.35^{\mathrm{B}}$ \\
\hline
\end{tabular}

Note: Mean \pm SE $(n=3)$; means within the same row with different uppercase letters are significantly different at $\mathrm{P}<0.05$, ${ }^{a} \mathrm{CPO}-\mathrm{crude}$ palm oil supplied by MPOB, ${ }^{b}$ RBDPO - refined, bleached, and deodorised palm oil supplied by MPOB, ${ }^{c}$ RBDPOo - refined, bleached and deodorised palm olein supplied by MPOB, ${ }^{\mathrm{d}} \mathrm{RBDPOs}$ - refined, bleached and deodorised palm stearin supplied by $\mathrm{MPOB},{ }^{\mathrm{e}} \mathrm{Crude}$ protein retention $=\{[($ final body crude protein $\times$ final body weight $/ 100)-($ initial body crude protein $\times$ initial body weight $/ 100)] \times 100\} /($ food intake $\times$ diet crude protein/100), ${ }^{\mathrm{f}}$ Crude lipid retention $=\{[($ final body crude lipid $\times$ final body weight $/ 100)-($ initial body crude lipid

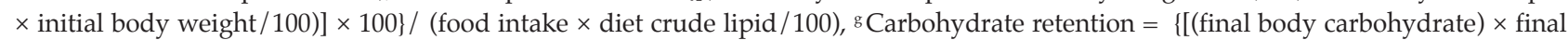
weight/100] $-[($ initial body carbohydrate $) \times$ initial weight/100] $\times 100\} /($ food intake $\times$ diet carbohydrate $/ 100)$, h Gross energy retention $=\{[($ final body gross energy $\times$ final body weight $/ 100)-($ initial body gross energy $\times$ initial body weight $/ 100)] \times 100\} /($ food intake $\times$ diet gross energy/100).

found in fish fed CPO compared to other treatments. Fish fed dietary $\mathrm{CPO}$ and RBDPO contained significantly higher $(\mathrm{P}<0.05)$ total $n-6$ PUFA than those fed dietary RBDPOs. The PUFA/SFA ratio was significantly higher $(\mathrm{P}<0.05)$ in the muscle of fish fed dietary CPO than the other treatments and a significantly lowest $(\mathrm{P}<0.05)$ ratio was observed in the muscle of fish fed dietary RBDPOs. The 16:1n-7 in juveniles fed RBDPOo was the highest but was only significantly higher $(\mathrm{P}<0.05)$ than the percentages in juveniles fed CPO and RBDPO. The lowest 16:1n-7 was found in juveniles given RBDPO.

The 18:2n-6 in the muscles of fish fed CPO and RBDPO were significantly higher $(\mathrm{P}<0.05)$ than that of fish given RBDPOs. The 20:4n-6, 22:5n-3 and 22:6n3 in juveniles fed dietary $\mathrm{CPO}$ were significantly higher $(P<0.05)$ than those of other treatments. The least 22:6n-3 content was found in the muscle of fish fed RBDPO diet. The 20:5n-3 found in fish fed CPO was significantly higher $(\mathrm{P}<0.05)$ than those in fish fed RBDPOo and RBDPO. No significant differences $(P>0.05)$ were found in the muscle $18: 3 n-3$ among the dietary treatments. Most PUFA (18:2n-6, 20:4n$6,22: 5 n-3$ and 22:6n-3) were relatively lower than their initial percentages before the feeding trial. On the contrary, SFA and monounsaturated fatty acids (MUFA) in the muscle of fish were in relatively higher percentages following the feeding. The $\mathrm{n}-3 / \mathrm{n}-6$ ratios in the muscle were more than its initial ratio.

The most dominant fatty acids in the fish liver was $18: 1 n-9$ followed by $16: 0,18: 0,16: 1 n-7$ and $18: 2 n-$ 6 (Table 7). The total n-6 PUFA and 18:2n-6 were significantly higher $(\mathrm{P}<0.05)$ in the liver of fish fed $\mathrm{CPO}$ and RBDPOo than those of fish fed RBDPOs. The PUFA/SFA ratios were significantly higher $(\mathrm{P}<0.05)$ in juveniles fed $\mathrm{CPO}$ and $\mathrm{RBDPO}$ compared to that of juveniles given RBDPOs. Meanwhile, 20:4n- 
TABLE 6. FATTY ACID COMPOSITION (\% of total fatty acids) OF MUSCLE TISSUE OF JUVENILE T. tambroides AT THE BEGINNING AND END OF THE 12-WEEK EXPERIMENTAL PERIOD

\begin{tabular}{|c|c|c|c|c|c|}
\hline & \multirow[b]{2}{*}{ Initial } & \multicolumn{4}{|c|}{ Experimental diet } \\
\hline & & $\mathrm{CPO}^{\mathrm{a}}$ & RBDPO $^{b}$ & $\mathrm{RBDPOo}^{\mathrm{c}}$ & RBDPOs $^{\mathrm{d}}$ \\
\hline 14:0 & 2.51 & $3.11 \pm 0.18$ & $3.17 \pm 0.18$ & $3.49 \pm 0.20$ & $3.44 \pm 0.20$ \\
\hline 16:0 & 26.47 & $32.46 \pm 1.88$ & $31.39 \pm 1.81$ & $32.48 \pm 1.88$ & $35.77 \pm 2.07$ \\
\hline $16: 1 n-7$ & 3.42 & $5.14 \pm 0.29^{\mathrm{AB}}$ & $4.48 \pm 0.26^{\mathrm{A}}$ & $6.51 \pm 0.38^{\mathrm{C}}$ & $5.81 \pm 0.33^{\mathrm{BC}}$ \\
\hline $18: 0$ & 6.99 & $7.81 \pm 0.45$ & $7.77 \pm 0.45$ & $6.90 \pm 0.40$ & $7.05 \pm 0.41$ \\
\hline $18: 1 n-9$ & 33.71 & $37.85 \pm 2.01$ & $41.73 \pm 2.05$ & $39.30 \pm 1.84$ & $37.40 \pm 2.06$ \\
\hline $18: 2 n-6$ & 18.76 & $6.97 \pm 0.40^{\mathrm{B}}$ & $6.97 \pm 0.40^{\mathrm{B}}$ & $6.11 \pm 0.35^{\mathrm{AB}}$ & $5.43 \pm 0.31^{\mathrm{A}}$ \\
\hline $18: 3 n-3$ & 1.30 & $1.30 \pm 0.08$ & $1.44 \pm 0.08$ & $1.47 \pm 0.09$ & $1.21 \pm 0.07$ \\
\hline $20: 4 n-6$ & 1.86 & $0.87 \pm 0.05^{\mathrm{B}}$ & $0.54 \pm 0.03^{\mathrm{A}}$ & $0.62 \pm 0.03^{\mathrm{A}}$ & $0.64 \pm 0.03^{\mathrm{A}}$ \\
\hline $20: 5 n-3$ & 0.54 & $0.64 \pm 0.03^{c}$ & $0.43 \pm 0.02^{\mathrm{a}}$ & $0.51 \pm 0.03^{\mathrm{AB}}$ & $0.57 \pm 0.03^{\mathrm{BC}}$ \\
\hline $22: 5 n-3$ & 0.45 & $0.32 \pm 0.02^{\mathrm{B}}$ & $0.19 \pm 0.01^{\mathrm{A}}$ & $0.23 \pm 0.01^{\mathrm{A}}$ & $0.23 \pm 0.01^{\mathrm{A}}$ \\
\hline $22: 6 n-3$ & 4.00 & $3.53 \pm 0.20^{C}$ & $1.90 \pm 0.11^{\mathrm{A}}$ & $2.38 \pm 0.14^{\mathrm{AB}}$ & $2.45 \pm 0.14^{\mathrm{B}}$ \\
\hline$\sum \mathrm{SFA}^{\mathrm{e}}$ & 35.96 & $43.38 \pm 2.15$ & $42.33 \pm 2.08$ & $42.87 \pm 2.07$ & $46.26 \pm 2.28$ \\
\hline$\Sigma \mathrm{UFA}^{\mathrm{f}}$ & 64.04 & $56.62 \pm 2.15$ & $57.67 \pm 2.08$ & $57.13 \pm 2.07$ & $53.74 \pm 2.28$ \\
\hline$\Sigma$ MUFA $^{g}$ & 37.13 & $42.99 \pm 2.31$ & $46.21 \pm 2.31$ & $45.81 \pm 2.22$ & $43.21 \pm 2.39$ \\
\hline$\sum \mathrm{n}-3$ PUFA $^{\mathrm{h}}$ & 6.30 & $5.79 \pm 0.29^{\mathrm{B}}$ & $3.96 \pm 0.20^{\mathrm{A}}$ & $4.59 \pm 0.24^{\mathrm{A}}$ & $4.46 \pm 0.24^{\mathrm{A}}$ \\
\hline$\sum$ n-6 PUFA ${ }^{\mathrm{i}}$ & 20.61 & $7.84 \pm 0.46^{\mathrm{B}}$ & $7.51 \pm 0.43^{\mathrm{B}}$ & $6.73 \pm 0.39^{\mathrm{AB}}$ & $6.07 \pm 0.35^{\mathrm{A}}$ \\
\hline$n-6 / n-3$ & 3.27 & $1.37 \pm 0.15$ & $1.92 \pm 0.21$ & $1.49 \pm 0.16$ & $1.38 \pm 0.15$ \\
\hline$n-3 / n-6$ & 0.31 & $0.75 \pm 0.08$ & $0.54 \pm 0.06$ & $0.69 \pm 0.08$ & $0.75 \pm 0.08$ \\
\hline UFA/SFA & 1.78 & $1.32 \pm 0.12$ & $1.37 \pm 0.12$ & $1.34 \pm 0.12$ & $1.17 \pm 0.11$ \\
\hline PUFA/SFA & 0.75 & $0.32 \pm 0.02^{\mathrm{C}}$ & $0.27 \pm 0.01^{\mathrm{B}}$ & $0.26 \pm 0.01^{\mathrm{B}}$ & $0.23 \pm 0.01^{\mathrm{A}}$ \\
\hline
\end{tabular}

Note: Mean \pm SE $(n=3)$; means within the same row with different uppercase letters are significantly different at $\mathrm{P}<0.05$, ${ }^{\text {a }} \mathrm{CPO}-\mathrm{crude}$ palm oil supplied by MPOB, ${ }^{\mathrm{b}}$ RBDPO - refined, bleached, and deodorised palm oil supplied by MPOB, ${ }^{\mathrm{c}}$ RBDPOo - refined, bleached and deodorised palm olein supplied by MPOB, ${ }^{\mathrm{d}}$ RBDPOs - refined, bleached and deodorised palm stearin supplied by MPOB, e SFA saturated fatty acids, ${ }^{\mathrm{f}}$ UFA - unsaturated fatty acids, ${ }^{\mathrm{g}}$ MUFA - monounsaturated fatty acids, ${ }^{\mathrm{h}} \mathrm{n}-3$ PUFA - the n-3 polyunsaturated fatty acids acids, ${ }^{i} n-6$ PUFA - the n- 6 polyunsaturated fatty acids.

6 and 22:6n-3 were significantly higher $(P<0.05)$ in juveniles fed RBDPO diet compared to those fed RBDPOo. Similar to the muscle, the liver of fish fed CPO had a significantly higher $(\mathrm{P}<0.05) 22: 5 \mathrm{n}-$ 3 percentage than those of other treatments. Most PUFA (18:2n-6, 20:4n-6, 20:5n-3, 22:5n-3 and 22:6n-3) and $n-6 / n-3$ ratios in the liver were lower after the feeding compared to the initial values. In contrast, total SFA and MUFA, and 18:3n-3 percentages in the liver were higher after the feeding.

The estimated fatty acid retentions of mahseer fed different types of palm oil are shown in Table 8. In general, the retentions of almost all fatty acids were higher than $100 \%$, except for 16:0 (in fish fed RBDPO and RBDPOo), 18:2n-6, 20:4n-6 (for those fed RBDPO, RBDPOo, and RBDPOs), and 22:5n3. This indicated that most of the fatty acids were accumulated from the non-lipid sources.

\section{DISCUSSION}

In this study, different palm oil products did not significantly affect the survival, growth performance, body indices, and lean percentage values of juvenile Malaysian mahseer. Mitochondrial $\beta$-oxidation of lipids and their constituent fatty acids provides metabolic energy in all organisms (Mishra and Samantaray, 2004). Ng et al. (2008) found no protein-sparing activity by dietary lipid containing a blend of corn oil and cod liver oil with low SFA content in Malaysian mahseer. In a later study, Ramezani-Fard et al. (2012b) observed that the high dietary SFA and MUFA contents will provide a readily available oxidised lipid source to provide the needed energy and spare protein for growth purposes in $T$. tambroides. Therefore, as all palm oil products used in this study contained high 16:0 and 18:1n-9 concentrations, no differences in the growth performances were found among juveniles fed various experimental diets. SFA and MUFA are preferred over PUFA for mitochondrial $\beta$-oxidation in fish (Henderson, 1996). However, MUFA with a double bond at an even-numbered carbon atom as well as PUFA can strongly prohibit other fatty acids $\beta$-oxidation during the intramitochondrial NADPH inadequacy (Osmundsen and Bjornstad, 1985). Therefore, SFA could be even preferred over MUFA for $\beta$-oxidation in fish.

The higher SGR values obtained by T. tambroides juveniles in this study than the previous studies (Ishak et al., 2016; Misieng et al., 2011; RamezaniFard et al., 2014; 2012b) could be as the result of using diets higher SFA, and lower MUFA and PUFA in the 
TABLE 7. FATTY ACID COMPOSITION (\% of total fatty acids) OF LIVER TISSUE OF JUVENILE T. tambroides AT THE BEGINNING AND END OF THE 12-WEEK EXPERIMENTAL PERIOD

\begin{tabular}{|c|c|c|c|c|c|}
\hline & \multicolumn{5}{|c|}{ Experimental diet } \\
\hline & Initial & $\mathrm{CPO}^{\mathrm{a}}$ & $\mathrm{RBDPO}^{\mathrm{b}}$ & $\mathrm{RBDPOo}^{\mathrm{c}}$ & RBDPOs $^{\mathrm{d}}$ \\
\hline $14: 0$ & 2.24 & $3.43 \pm 0.20$ & $3.43 \pm 0.20$ & $3.81 \pm 0.22$ & $3.69 \pm 0.21$ \\
\hline $16: 0$ & 26.87 & $29.00 \pm 1.67$ & $29.60 \pm 1.71$ & $30.39 \pm 1.76$ & $31.94 \pm 1.84$ \\
\hline $16: 1 n-7$ & 4.71 & $6.12 \pm 0.35$ & $5.89 \pm 0.34$ & $6.67 \pm 0.39$ & $6.95 \pm 0.40$ \\
\hline $18: 0$ & 7.79 & $8.51 \pm 0.49$ & $8.24 \pm 0.47$ & $7.30 \pm 0.42$ & $7.81 \pm 0.45$ \\
\hline $18: 1 n-9$ & 31.65 & $39.78 \pm 1.81$ & $40.57 \pm 1.74$ & $39.63 \pm 1.76$ & $38.39 \pm 1.76$ \\
\hline $18: 2 n-6$ & 14.97 & $6.77 \pm 0.39^{\mathrm{B}}$ & $5.92 \pm 0.34^{\mathrm{AB}}$ & $6.86 \pm 0.40^{\mathrm{B}}$ & $5.41 \pm 0.31^{\mathrm{A}}$ \\
\hline $18: 3 n-3$ & 1.28 & $1.55 \pm 0.09$ & $1.86 \pm 0.11$ & $1.59 \pm 0.09$ & $1.83 \pm 0.10$ \\
\hline $20: 4 n-6$ & 2.15 & $0.83 \pm 0.05^{\mathrm{AB}}$ & $0.85 \pm 0.05^{\mathrm{B}}$ & $0.69 \pm 0.04^{\mathrm{A}}$ & $0.71 \pm 0.04^{\mathrm{AB}}$ \\
\hline $20: 5 n-3$ & 0.80 & $0.69 \pm 0.04$ & $0.70 \pm 0.04$ & $0.70 \pm 0.04$ & $0.60 \pm 0.03$ \\
\hline $22: 5 n-3$ & 1.08 & $0.70 \pm 0.04^{\mathrm{B}}$ & $0.22 \pm 0.01^{\mathrm{A}}$ & $0.19 \pm 0.01^{\mathrm{A}}$ & $0.22 \pm 0.01^{\mathrm{A}}$ \\
\hline $22: 6 n-3$ & 6.47 & $2.61 \pm 0.15^{\mathrm{AB}}$ & $2.71 \pm 0.16^{\mathrm{B}}$ & $2.18 \pm 0.13^{\mathrm{A}}$ & $2.46 \pm 0.14^{\mathrm{AB}}$ \\
\hline$\Sigma \mathrm{SFA}^{\mathrm{e}}$ & 36.89 & $40.94 \pm 1.97$ & $41.28 \pm 1.99$ & $41.49 \pm 1.96$ & $43.44 \pm 2.08$ \\
\hline$\Sigma \mathrm{UFA}^{\mathrm{f}}$ & 63.11 & $59.06 \pm 1.97$ & $58.72 \pm 1.99$ & $58.51 \pm 1.96$ & $56.56 \pm 2.08$ \\
\hline$\Sigma$ MUFA $^{g}$ & 36.36 & $45.90 \pm 2.17$ & $46.46 \pm 2.08$ & $46.29 \pm 2.15$ & $45.33 \pm 2.16$ \\
\hline$\sum$ n-3 PUFA $^{\mathrm{h}}$ & 9.63 & $5.56 \pm 0.24$ & $5.49 \pm 0.30$ & $4.66 \pm 0.25$ & $5.11 \pm 0.27$ \\
\hline$\sum$ n-6 PUFA ${ }^{\mathrm{i}}$ & 17.12 & $7.61 \pm 0.44^{\mathrm{B}}$ & $6.77 \pm 0.39^{\mathrm{AB}}$ & $7.55 \pm 0.44^{\mathrm{B}}$ & $6.11 \pm 0.35^{\mathrm{A}}$ \\
\hline$n-6 / n-3$ & 1.78 & $1.38 \pm 0.14$ & $1.25 \pm 0.14$ & $1.64 \pm 0.18$ & $1.21 \pm 0.13$ \\
\hline$n-3 / n-6$ & 0.56 & $0.74 \pm 0.08$ & $0.82 \pm 0.09$ & $0.63 \pm 0.07$ & $0.85 \pm 0.09$ \\
\hline UFA/SFA & 1.71 & $1.45 \pm 0.12$ & $1.43 \pm 0.12$ & $1.42 \pm 0.11$ & $1.31 \pm 0.11$ \\
\hline PUFA/SFA & 0.73 & $0.32 \pm 0.01^{\mathrm{B}}$ & $0.30 \pm 0.01^{\mathrm{B}}$ & $0.29 \pm 0.01^{\mathrm{AB}}$ & $0.26 \pm 0.01^{\mathrm{A}}$ \\
\hline
\end{tabular}

Note: Mean $\pm \mathrm{SE}(\mathrm{n}=3)$; means within the same row with different uppercase letters are significantly different at $\mathrm{P}<0.05$, ${ }^{\mathrm{a}} \mathrm{CPO}$ - crude palm oil supplied by MPOB, ${ }^{b}$ RBDPO - refined, bleached, and deodorised palm oil supplied by MPOB, ${ }^{\mathrm{R}}$ RDPOO - refined, bleached and deodorised palm olein supplied by MPOB, ${ }^{\mathrm{d}}$ RBDPOs - refined, bleached and deodorised palm stearin supplied by MPOB, ${ }^{\mathrm{e}}$ SFA saturated fatty acids, ${ }^{\mathrm{f}} \mathrm{UFA}$ - unsaturated fatty acids, ${ }^{\mathrm{g}}$ MUFA - monounsaturated fatty acids, ${ }^{\mathrm{h}} \mathrm{n}-3$ PUFA - the $\mathrm{n}-3$ polyunsaturated fatty acids, ${ }^{\text {in}} \mathrm{n}-6$ PUFA - the $\mathrm{n}-6$ polyunsaturated fatty acids.

TABLE 8. FATTY ACID RETENTIONS (\% dietary respective fatty acid) OF MUSCLE OF JUVENILE T. tambroides FED ON DIFFERENT EXPERIMENTAL DIETS

\begin{tabular}{|c|c|c|c|c|}
\hline & \multicolumn{4}{|c|}{ Experimental diet } \\
\hline & $\mathrm{CPO}^{\mathrm{a}}$ & $\mathrm{RBDPO}^{\mathrm{b}}$ & $\mathrm{RBDPOo}^{\mathrm{c}}$ & RBDPOs $^{d}$ \\
\hline $14: 0$ & $164.07 \pm 44.98$ & $140.25 \pm 9.97$ & $149.49 \pm 32.68$ & $208.86 \pm 23.28$ \\
\hline $16: 0$ & $110.13 \pm 15.28$ & $87.98 \pm 12.43$ & $85.94 \pm 20.89$ & $101.22 \pm 15.75$ \\
\hline $16: 1 n-7$ & $347.01 \pm 91.82$ & $241.69 \pm 16.94$ & $328.96 \pm 69.32$ & $406.13 \pm 42.79$ \\
\hline $18: 0$ & $163.71 \pm 23.21$ & $137.61 \pm 19.62$ & $100.19 \pm 25.68$ & $157.01 \pm 26.21$ \\
\hline $18: 1 n-9$ & $148.50 \pm 40.84$ & $133.10 \pm 9.13$ & $112.31 \pm 24.83$ & $204.99 \pm 24.46$ \\
\hline $18: 2 n-6$ & $54.39 \pm 14.67$ & $56.90 \pm 12.26$ & $26.16 \pm 17.70$ & $47.46 \pm 28.26$ \\
\hline $18: 3 n-3$ & $290.73 \pm 83.74^{\mathrm{A}}$ & $410.75 \pm 30.33^{\mathrm{AB}}$ & $377.43 \pm 85.48^{\mathrm{AB}}$ & $622.51 \pm 80.33^{\mathrm{B}}$ \\
\hline $20: 4 n-6$ & $124.44 \pm 25.71^{\mathrm{B}}$ & $32.11 \pm 9.81^{\mathrm{A}}$ & $36.08 \pm 23.44^{\mathrm{A}}$ & $65.99 \pm 25.40^{\mathrm{AB}}$ \\
\hline $20: 5 n-3$ & $194.73 \pm 53.05$ & $94.23 \pm 8.05$ & $102.87 \pm 24.18$ & $165.16 \pm 20.33$ \\
\hline $22: 5 n-3$ & $72.24 \pm 12.22 \mathrm{~B}$ & $27.72 \pm 5.68^{\mathrm{A}}$ & $30.88 \pm 10.98^{\mathrm{A}}$ & $55.29 \pm 12.45^{\mathrm{AB}}$ \\
\hline $22: 6 n-3$ & $572.40 \pm 170.52^{\mathrm{B}}$ & $177.90 \pm 24.24^{\mathrm{A}}$ & $227.05 \pm 62.97^{\mathrm{A}}$ & $349.86 \pm 59.01^{\mathrm{AB}}$ \\
\hline$\Sigma$ SFA $^{\mathrm{e}}$ & $120.02 \pm 17.93$ & $97.05 \pm 12.80$ & $91.18 \pm 21.73$ & $111.13 \pm 16.75$ \\
\hline$\Sigma$ MUFA $^{\mathrm{f}}$ & $160.01 \pm 43.79$ & $139.22 \pm 9.56$ & $125.07 \pm 27.44$ & $221.70 \pm 26.01$ \\
\hline$\sum$ n-3 PUFA' & $321.29 \pm 92.07$ & $170.37 \pm 16.77$ & $183.74 \pm 46.24$ & $277.29 \pm 41.39$ \\
\hline$\sum$ n-6 PUFA ${ }^{\mathrm{h}}$ & $68.88 \pm 17.97$ & $54.93 \pm 12.05$ & $26.88 \pm 18.12$ & $48.79 \pm 28.61$ \\
\hline
\end{tabular}

Note: Mean \pm SE $(n=3)$; means within the same row with different uppercase letters are significantly different at $P<0.05$, fatty acid retention $(\%)=\{[($ final muscle fatty acid $\times$ final muscle crude lipid $\times$ dry matter $\times$ final muscle weight $/ 100)$ - (initial muscle fatty acid $\times$ initial muscle crude lipid $\times$ dry matter $\times$ initial muscle weight $/ 100)] \times 100\} /($ food intake $\times$ diet fatty acid $\times$ diet crude lipid), a CPO - crude palm oil supplied by MPOB, ${ }^{b}$ RBDPO - refined, bleached, and deodorised palm oil supplied by MPOB, ${ }^{c}$ RBDPOo - refined, bleached and deodorised palm olein supplied by MPOB, ${ }^{\mathrm{d}} \mathrm{RBDPO}$ - refined, bleached and deodorised palm stearin supplied by MPOB, ${ }^{\mathrm{e}} \mathrm{SFA}$ - saturated fatty acids, ${ }^{\mathrm{f}}$ MUFA - monounsaturated fatty acids, ${ }^{\mathrm{g} n} \mathrm{n}-3$ PUFA - the $\mathrm{n}-3$ polyunsaturated fatty acids, ${ }^{\mathrm{h}} \mathrm{n}-6$ PUFA - the n-6 polyunsaturated fatty acids. 
current research compared to the diets used in those studies. However, Ramezani-Fard et al. (2012a) have achieved higher SGR (1.39-1.94) in T. tambroides juveniles with higher DFI (1.85-3.83) than this study as the same authors have demonstrated that higher DFI results in better growth performance of this fish. Ng and Andin (2011) also have reported higher SGR (1.81-2.03) in Malaysian mahseer juveniles fed with diets containing higher protein $(42.7 \%-43.5 \%)$ and lipid (3\%-19.1\%) than this study. The same researchers, however, have achieved SGR values comparable to this study with T. tambroides juveniles fed semi-purified diets including $40.6 \%-42 \%$ protein and $3.7 \%-4.3 \%$ lipid. $\mathrm{Ng}$ et al. (2008) have reported SGR values similar to this study (1.20-1.68 per day) using $20.9 \pm 0.1 \mathrm{~g}$ pond-raised F1 T. tambroides fish fed semi-purified diets $(31.9 \%-52.2 \%$ protein and 8.8\%-10.4\% lipid). They obtained higher SGR (2.883.21 per day) using smaller $0.67 \pm 0.15 \mathrm{~g}$ fish fed semi-purified diets with $31.8 \%-40.5 \%$ protein and 14.5\%-14.9\% lipid.

The FCR values obtained by $T$. tambroides juveniles in this study were reasonable low for a slow growing fish. This could be as the result of appropriate feeding schedule, proper utilisation of feed and high digestibility of feed ingredients. The FCR observed in the current research were in the range of those obtained in the previous studies (Ishak et al., 2016; Misieng et al., 2011; Ng and Andin, 2011; Ramezani-Fard et al., 2014; 2012a). The lower FCR = better FCR, and higher energy and protein retention values were found in T. tambroides juveniles fed on RBDPOs and might be as a result of higher 16:0 concentration in spite of lower 18:1n9 concentration of RBDPOs compared to other experimental palm oil products. Moreover, this could be the reason for the higher and body protein of juveniles fed RBDPOs than those fed other test diets, although the differences were not significant.

The high VSI values reaffirmed the high tendency of T. tambroides to deposit fat in the visceral cavity (Ng et al., 2008; Ramezani-Fard et al., 2012b). The EFA deficiency in fish leads to the increase of hepatocytes de novo fatty acid synthesis and the enhancement of tissue lipid content. Conversely, fatty acid oxidation results in depletion of lipid content (Ferrini et al., 2010; Vamecq et al., 1993). Since the body lipid content remained similarly very high for all treatments, higher VSI in fish fed CPO and RBDPO diet suggested the higher visceral fat deposition was strongly related to the higher antioxidant ability of these oils. Although RBDPO, being the first product of $\mathrm{CPO}$ refining, contains more carotenoids and hence more antioxidant capacity than RBDPOo and RBDPOs $(\mathrm{Ng}$ et al., 2003), it does not have as much antioxidant activity as $\mathrm{CPO}$.

The high levels of body protein, lipid and energy, and low body carbohydrate and dietary carbohydrate retention along with high dietary lipid retention indicate that the fish was able to use most of the dietary carbohydrate to provide its required energy and to convert it into its body lipid. Recently, Ishak et al. (2016) have reported an optimal dietary carbohydrate level of $23.4 \%$ for this fish. These researchers have observed a decreased growth in Malaysian mahseer fed higher than 25\% dietary carbohydrate. Kamarudin et al. (2014) have mentioned that corn starch is the best carbohydrate source for this fish followed by taro, sago and tapioca starch. In the current research, dietary levels of protein and lipid were according to the nutritional requirements of $T$. tambroides juveniles, which included 5\%-10\% lipid ( $\mathrm{Ng}$ and Andin, 2011; Ramezani-Fard et al., 2012a) and 40\% protein (Misieng et al., 2011). However, the carbohydrate levels of the diets were higher than $25 \%$ and tapioca starch was used as the dietary carbohydrate source that might prevent a better growth of the fish. In spite of similar survival rates, growth performance, lean percentages, body indices, and chemical body composition, differences in tissue fatty acid composition and fatty acid retention of juveniles fed various palm oil products were observed.

The 14:0, 16:0, 16:1n-7, 17:0, 18:0, 18:1n-9, 18:2n6, 18:3n-3, 20:3n-6, 20:5n-3 and 22:6n-3 are important fatty acids of freshwater species. In this study, these fatty acids except for 17:0 and 20:3n-6 were detected in T. tambroides muscle. The dietary fatty acid composition quickly affects the fatty acid profile of fish tissue (Tan et al., 2009). Lower 16:0 percentages were found in both muscle (31.39\%-35.75\%) and liver $(29.0 \%-30.39 \%)$ of fish fed different dietary palm oils despite being fed with diets containing $40.65 \%-55.02 \%$ of $16: 0$, although its retention ranged $85.9 \%-110.1 \%$. Selective depletion of this fatty acid in muscle tissues indicates that this fish mobilises and catabolises 16:0 more than the other fatty acids for energy provision for fish (Tan et al., 2009). However, a change of diet can alter the inclination of a fatty acid to be catabolised by a specific species. Ramezani-Fard et al. (2012b) found that $T$. tambroides fed different ratios of dietary RBDPOo, crude palm kernel oil (CPKO), olive oil and cod liver oil favours 18:2n-6 for catabolism, while they selectively retain 16:0 in their muscle. Bell et al. (2001) observed that the Atlantic salmon tends to catabolise 20:1n-9 and 22:1n-11 when fed diets containing different dietary rapeseed oil ratios and selectively retain these fatty acids when fed diets containing different dietary palm oil ratios (Bell et al., 2002). Moreover, the 16:0 reduction is often associated with the 16:1n-7 increment in both liver and muscle, which demonstrates the desaturation and elongation of $16: 0$ to $16: 1 \mathrm{n}-7$ in fish tissues. A much higher 16:1n-7 retention (242\%-406\%) was observed in this study compared to the 16:0 retention. 
High percentages of $18: 1 n-9$ were found in the muscle of juveniles with the most retention observed among fish fed RBDPOs that contained the lowest 18:1n-9 percentage. The selective retention of 18:1n-9 in T. tambroides muscle had been reported by Ramezani-Fard et al. (2012b) and in yellow catfish (Pelteobagrus fulvidraco) by Tan et al. (2009).

In addition to dietary fats, the body deposited fat can be obtained from de novo fat synthesis of non-fat nutrients (Hepher, 1988). Acetate is a critical precursor for de novo fatty acid synthesis in fish. Carbohydrates and protein are first transformed into acetate-CoA to form CoA-thioester, and the provision of phosphatides, fatty acids and fats is done through several steps. Fatty acid synthesis from carbohydrates seems to be majorly conducted in the hepatic tissue (Hepher, 1988). Farkas et al. (1961) found that the most de novo fatty acid synthesis belongs to SFA, with a proportion of fifth to a quarter for unsaturated fatty acids (UFA). It has been reported that a high lipid, low carbohydrate diet reduces the activity of the enzymes that corporate in fatty acid synthesis (Hepher, 1988).

Despite having a low optimal dietary lipid requirement of $5 \%-10 \%(\mathrm{Ng}$ and Andin, 2011; Ramezani-Fard et al., 2012a) and being fed a low dietary lipid (8\%), mahseer was a fatty fish with $15.8 \%-18.3 \%$ body lipid (wet weight basis) which was as much as body protein, and $175.3 \%-248.2 \%$ lipid retention. These findings strongly indicated that the fish was able to perform de novo synthesis body lipid from the non-fat dietary components particularly carbohydrates, which showed retention of $2.6 \%-10.8 \%$. The ability of converting dietary carbohydrate into body lipid has been reported in grass carp and hybrid tilapia (Guo et al., 2015; Tian et al., 2012; Wang et al., 2005).

High levels of total n-3 PUFA were found in both muscle and liver of fish fed different types of palm oil products than the levels in the experimental diets. In addition, the total n-3 PUFA in these individual oils were extremely low $(0.1 \%-0.2 \%)$ while the longchain PUFA (20:4n-6, 20:5n-3, 22:5n-3 and 22:6n-3) were absent. It has been suggested that sparing and maintaining the n-3 PUFA levels in fish tissues are possible by having sufficient SFA and MUFA in its diet (Mishra and Samantaray, 2004). RamezaniFard et al. (2012b) found that adequate dietary 16:0 and $18: 1 n-9$ (the readily oxidised fatty acids in carp liver mitochondria) leads to n-3 PUFA retention in the tissues of $T$. tambroides, while insufficient dietary $16: 0$ and 18:1n-9 levels lead to n-3 PUFA mobilisation and catabolism for energy generation purposes. Fish needs a minimum dietary content of n-3 PUFA in their diet to retain the tissue n-3 PUFA level (Hepher, 1988). Ramezani-Fard et al. (2012b) speculated that the residual fish oil from fishmeal is adequate for $T$. tambroides for selective retention of $22: 6 n-3$ in the muscle. A relative $22: 6 n-3$ retention has also been observed in tilapia (Bahurmiz and $\mathrm{Ng}$, 2007) and African catfish ( $\mathrm{Ng}$ et al., 2003). In this study, the retention of 22:6n-3 ranged 1.7-5.7-folds of the total 22:6n-3 consumed by the fish. The high retention values of 22:6n-3 also indicated that this fatty acid can be de novo synthesised from the dietary $18: 3 n-3$ by elongation and desaturation. The low 22:5n-3 retention $(27.7 \%-30.9 \%)$ in fish fed RBDO and RBDPO and only 1.7-2.3 folds of 22:6n3 suggested higher oxidisation of these fatty acids in the muscle of these groups of juveniles compared to those fed CPO and RBDPOs. Moreover, fish can readily $\beta$-oxidise $20: 5 n-3$, but they can use $22: 6 n-3$ as a source of energy if necessary since $22: 6 n-3$ needs to be $\beta$-oxidized in the peroxisomes and mitochondria (Tocher, 2003). In addition, 20:5n-3 can be elongated and desaturated to produce $22: 6 n-3$. This could be the reason of higher deposition and retention of 22:6n-3 in the tissue of T. tambroides juveniles fed the experimental diets.

High 22:5n-3 and 22:6n-3 retention values were observed in the tissue of fish fed CPO. Since PUFA (especially n-3 LC-PUFA) are highly susceptible to oxidation ( $\mathrm{Ng}$ et al., 2003), high vitamin E content in $\mathrm{CPO}$ could be another main reason of higher contents and retentions of long chain PUFA were preserved in the muscle of fish fed CPO. In spite of the highest 16:0 concentration in the RBDPOs diet, slightly lower retentions of $22: 5 n-3$ and $22: 6 n-$ 3 occurred in the muscle tissue of juveniles fed on this diet than those fed on the CPO diet. RamezaniFard et al. (2012b) have reported the tendency of Malaysian mahseer to mobilise and catabolise $18: 2 n-6$ as an efficient energy source in its body. The lower $18: 2 n-6$ contents in the muscle $(5.43 \%-6.97 \%)$ and liver $(5.41 \%-6.86 \%)$ of $T$. tambroides juveniles along with its low muscular retention (26.2\%$56.9 \%$ ) reaffirmed their notion. Therefore, higher $18: 1 n-9$ and $18: 2 n-6$ contents in the CPO diet than the RBDPOs diet could prevent n-3 LC-PUFA from being $\beta$-oxidised and thus, could result in their slightly higher retentions in the muscle of fish fed on CPO compared to those fed on RBDPOs.

Ramezani-Fard et al. (2012b) suggested that the musclen-3 PUFA in mahseer are majorly constituted by de novo synthesis rather than a direct absorption from the diet. The high retention (94.2\%-622.5\%) of $18: 3 n-3,20: 5 n-3$ and $22: 6 n-3$ in the tissue of fish supported the view of Hepher (1988) that the fatty acids were de novo synthesised from dietary nonfat nutrients. Although the RBDPO diet contained the highest amount of 16:0, it had the least amount of $18: 1 n-9,18: 2 n-6$, and $18: 3 n-3$, which should not be sufficient for an efficient retention of n-3 PUFA in the juvenile tissues solely from the dietary lipid source. However, the muscular 22:6n-3 and 18:3n3 retention in juveniles fed RBDPO were 3.5-6.2 folds of the consumed fatty acids. The findings reaffirmed the notion that the mahseer was able to 
de novo synthesis of PUFA from non-lipid dietary sources.

This study showed that the total muscular n-3 PUFA in mahseer were lower than their initial composition. Farkas (1984) suggested that a lower water temperature will increase carp tissue PUFA. The mean water temperature in the current research was approximately $10^{\circ} \mathrm{C}$ higher than that of the natural waters where the juveniles inhabit (about $18^{\circ} \mathrm{C}$ ).

A permanent competition between the $n-3$ and $\mathrm{n}-6$ families for access to the elongase and desaturase enzymes may retard the conversion of $18: 2 n-6$ to $20: 4 n-6$. Desaturases $\Delta 5$ and $\Delta 6$ tend to use the n-3 more than n-6 PUFA (Turchini et al., 2006). In the present study, the proportion of $18: 2 n-$ 6 and 20:4n-6 in both liver and muscle of fish were lower than those found before the feeding trial. The dietary retention of $18: 2 n-6$ in the fish muscle ranged from $56.9 \%$ to $26.2 \%$ depending on the palm oil type while the retention of 20:4n-6 among fish fed RBDPO and RBDPOo was only about $32 \%$ and $36 \%$, about $66 \%$ for those fed RBDPOs and almost $124 \%$ for those given $\mathrm{CPO}$. These findings indicated that the conversion of $18: 2 n-6$ to $20: 4 n-6$ could not have happened among fish fed RBDO and RBDPO, but a little conversion might have happened among those fed RBDPOs, and the de novo synthesis of 20:4n6 from non-lipid sources along with some level of 18:2n-6 elongation were likely to have occurred among juveniles fed CPO. The dependence of 20:4n6 content in fish tissues on its dietary content has been reported previously by Jankowska et al. (2010). In general, all fish presented the muscle $n-3 / n-6$ ratios better than recommended ratios (0.1-0.2) by the World Health Organisation (Tanamati et al., 2009). However, CPO gave a better retention of $n-3$ and n-6 LC-PUFA.

\section{CONCLUSION}

In conclusion, the results of this study demonstrated that all the tested palm oil products gave similar survival, growth and body composition to mahseer juveniles. However, CPO gave a better fatty acid composition of fish, especially with the longer chain PUFA. The CPO diet, which contained a high 16:0 and 18:1n-9 concentrations and a moderate 18:2n-6 content, was used efficiently as the main energy sources by $T$. tambroides and this therefore led to the high maintenance of $n-3$ and n-6 LCPUFA in the muscle tissue of juveniles fed on CPO. Moreover, $\mathrm{CPO}$ contains a high carotenoid content that enables a high antioxidation capacity and a better maintenance of PUFA in the fish tissues. This is especially important in the case of n-3 LCPUFA. Furthermore, being the cheapest and basic form of palm oil, the use of CPO should be more cost-effective compared to the other types of palm oil while at the same time reducing the carbon footprint. Therefore, $\mathrm{CPO}$ was recommended as the lipid source in the diet of T. tambroides juvenile.

\section{REFERENCES}

AHLGREN, G; BLOMQVIST, P; BOBERG, $\mathrm{M}$ and GUSTAFSSON, I B (1994). Fatty acid content of the dorsal muscle - an indicator of fat quality in freshwater fish. J. Fish Biol., 45: 131-157.

AL-OWAFEIR, M A and BELAL, I E H (1996). Replacing palm oil for soybean oil in tilapia, Oreochromis niloticus (L.), feed. Aquacult. Res., 27: 221-224.

AOAC (1997). Official Methods of Analysis of the Association of Official Analytical Chemists. Washington, DC, AOAC International.

BABALOLA, T O and APATA, D F (2012). Effect of dietary palm oil on growth and carcass composition of Heterobranchus longifilis fingerlings. JCEA, 13: 782791.

BAHURMIZ, O M and NG, W (2007). Effects of dietary palm oil source on growth, tissue fatty acid composition and nutrient digestibility of red hybrid tilapia, Oreochromis sp., raised from stocking to marketable size. Aquaculture, 262: 382-392.

BELL, J G; HENDERSON, R J; TOCHER, D R; MCGHEE, F; DICK, J R; PORTER, A and SARGENT, J R (2002). Substituting fish oil with crude palm oil in the diet of Atlantic salmon (Salmo salar) affects muscle fatty acid composition and hepatic fatty acid metabolism. J. Nutr., 132: 222-230.

BELL, J G; MCEVOY, J; TOCHER, D R; MCGHEE, F; CAMPBELL, P J and SARGENT, J R (2001). Replacement of fish oil with rapeseed oil in diets of Atlantic salmon (Salmo salar) affects tissue lipid compositions and hepatocyte fatty acid metabolism. J. Nutr., 131: 1535-1543.

DOF (2012). Annual Fisheries Statistics 2011. Department of Fisheries, Malaysia.

DOF (2013). Annual Fisheries Statistics 2012. Department of Fisheries, Malaysia.

DOF (2014). Annual Fisheries Statistics 2013. Department of Fisheries, Malaysia.

DOF (2015). Annual Fisheries Statistics 2014. Department of Fisheries, Malaysia.

DOF (2016). Annual Fisheries Statistics 2015. Department of Fisheries, Malaysia. 
ESA, Y; KAMARUDDIN, K R; ABD RAHIM, K A; DAUD, S K; SIRAJ, S S and TAN, S G (2007). Phylogenetic relationships among three mahseers of the subtribe Tores in Malaysia. The Biology, Culture and Conservation (Siraj, S S; Christianus, $\mathrm{A}$ and $\mathrm{Ng}$, C K eds.). Occasional Publication No. 14. Malaysian Fisheries Society.

FAO (2015). Oil seeds and oilseed products. OECDFAO Agricultural Outlook 2015. www.fao.org/ fileadmin/templates / est/COMM_MARKETS_ MONITORING/Oilcrops/OCED_Reports/OCED_ oilseeds2015_2024.pdf, accessed on 1 February 2016 from:

FARKAS, T (1984). Adaptation of fatty acid composition to temperature - a study on carp (Cyprinus carpio L.) liver slices. Comp. Biochem. Physiol. B. Biochem. Mol. Biol., 79: 531-535.

FARKAS, T; HERODEK, S; GSÁKY, L and TÓTH, G (1961). Incorporation of acetate- $1-{ }^{14} \mathrm{C}$ into the liver fatty acids in the fish Amiurus nebulosus. Acta Biol. Acad. Sci. H., 12: 83-86.

FERRINI, G; MANZANILLA, E G; MENOYO, D; ESTEVE-GARCIA, E; BAUCELLS, M D and BARROETA, A C (2010). Effects of dietary n-3 fatty acidsin fat metabolism and thyroid hormone levels when compared to dietary saturated fatty acids in chickens. Livest. Sci., 131: 287-291.

GUO, X; LIANG, X F; FANG, L; YUAN, X; ZHOU, Y; ZHANG, J and LI, B (2015). Effects of dietary nonprotein energy source levels on growth performance, body composition and lipid metabolism in herbivorous grass carp (Ctenopharyngodon idella Val.). Aquacult. Res., 46: 1197-1208.

HENDERSON, J R (1996). Fatty acid metabolism in freshwater fish with particular reference to polyunsaturated fatty acids. Arch. Anim. Nutr., 49: 5-22.

HEPHER, B (1988). Nutrition of Pond Fishes. Cambridge University Press.

HOULIHAN, D; BOUIARD, T and JOBLING, M (2001). Food Intake in Fish. Oxford, Blackwell Science Ltd.

INGRAM, B A; SUNGAN, S; GOOLEY, G J; SIM, S Y; TINGGI, D and DE SILVA, S S (2005). Induced spawning, larval development and rearing of two indigenous Malaysian mahseer, Tor tambroides and T. douronensis. Aquacult. Res., 36: 1001-1014.

INGRAM, B A; SUNGAN, S; TINGGI, D; SIM, S Y; GOOLEY, G J and DE SILVA, S S (2007).
Observation on the growth of cage- and pondreared Tor tambroides and Tor douronensis in Sarawak, Malaysia. Mahseer: The Biology, Culture and Conservation (Siraj, S S; Christianus, A and Ng, C K eds.). Occasional Publication No. 14. Malaysian Fisheries Society.

ISHAK, S D; KAMARUDIN, M S; RAMEZANIFARD, E; SAAD, C R and YUSOF, Y A (2016). Effects of varying dietary carbohydrate levels on growth performance, body composition and liver histology of Malaysian mahseer fingerlings (Tor tambroides). J. Env. Biol., 37: 755-764.

JANKOWSKA, B; ZAKÉŚ, Z; ŻMIJEWSKI, T and SZCZEPKOWSKI, M (2010). Fatty acid profile of muscles, liver and mesenteric fat in wild and reared perch (Perca fluviatilis L.). Food Chem., 118: 764-768.

KAMARUDIN, M S; RAMEZANI-FARD, E; ISHAK, S D; DE CRUZ, C Rl BAMI, M Ll HARRIS, M H I and MISIENG, J D (2014). Feeding and nutrition of endangered mahseers: a review. Keynote Paper. International Conference of Aquaculture Indonesia. Bandung: Universitas Padjajaran.

KAMARUDIN, M S; RAMEZANI-FARD, E; SAAD, C R and HARMIN, S A (2012). Effects of dietary fish oil replacement by various vegetable oils on growth performance, body composition and fatty acid profile of juvenile Malaysian mahseer, Tor tambroides. Aquacult. Nutr., 18: 532-543.

LEGENDRE, M; KERDCHUAN, N; CORRAZE, G and BERGOT, P (1995). Larval rearing of an African catfish Heterobranchus longifilis (Teleostei, Clariidae): effect of dietary lipids on growth, survival and fatty acid composition of fry. Aquat. Living Resour., 8: 355363.

LIM, P K; BOEY, P L and NG, W K (2001). Dietary palm oil level affects growth performance, protein retention and tissue vitamin $\mathrm{E}$ concentration of African catfish, Clarias gariepinus. Aquaculture, 202: 101-112.

MISHRA, K and SAMANTARAY, K (2004). Interacting effects of dietary lipid level and temperature on growth, body composition and fatty acid profile of rohu, Labeo rohita (Hamilton). Aquacult. Nutr., 10: 359-369.

MISIENG, J D; KAMARUDIN, M S and MUSA, M (2011). Optimum dietary protein requirement of Malaysian mahseer (Tor tambroides) fingerling. Pak. J. Biol. Sci., 14: 232-235.

MOREIRA, A B; VISENTAINER, J V; DE SOUZA, N E and MATSUSHITA, M (2001). Fatty acids profile 
and cholestrol contents of three Brazilian Brycon freshwater fishes. J. Food Comp. Anal., 14: 565-574.

NESARETNAM, K and MUHAMMAD, B (1993). Nutritional properties of palm oil. Selected Readings on Palm Oil and its Uses. PORIM, Bangi.

NG, C K (2004). King of the Rivers: Mahseer in Malaysia and the Region. Inter Sea Fishery Ltd.

NG, W K (2002). Potential of palm oil utilisation in aquaculture feeds. Asia Pac. J. Clin. Nutr., 11: 473-476.

NG, W K; ABDULLAH, N and DE SILVA, S S (2008). The dietary protein requirement of the Malaysian mahseer, Tor tambroides (Bleeker), and the lack of protein-sparing action by dietary lipid. Aquaculture, 284: 201-206.

NG, W K and ANDIN, V C (2011). The Malaysian mahseer, Tor tambroides (Bleeker), requires low dietary lipid levels with a preference for lipid sources with high omega- 6 and low omega- 3 polyunsaturated fatty acids. Aquaculture, 322-323: 82-90.

NG, W K; LIM, P K and BOEY, P L (2003). Dietary lipid and palm oil source affects growth, fatty acid composition and muscle $\alpha$-tocopherol concentration of African catfish, Clarias gariepinus. Aquaculture, 215: 229-243.

NG, W K and WANG, Y (2011). Inclusion of crude palm oil in the broodstock diets of female Nile tilapia, Oreochromis niloticus, resulted in enhanced reproductive performance compared to broodfish fed diets with added fish oil or linseed oil. Aquaculture, 314: 122-131.

OSMUNDSEN, H and BJORNSTAD, K (1985). Inhibitory effects of some long-chain unsaturated fatty acids on mitochondrial $\beta$-oxidation. Biochem. J., 230: 329-337.

ÖZOGUL, Y; ÖZOGUL, F and ALAGOZ, S (2007). Fatty acid profiles and fat contents of commercially important seawater and freshwater fish species of Turkey: a comparative study. J. Food Chem., 103: 217223.

PANTZARIS, T P (1997). Pocketbook of Palm Oil Uses. PORIM, Bangi.

RAMEZANI-FARD, E; KAMARUDIN, M S; EHTESHAMI, Fl SHAKIBA ZADEH, Sl SAAD, $\mathrm{C} R$ and ZOKAEIFAR, H (2014). Effect of dietary linolenic acid (18:3n-3)/linoleic acid (18:2n-6) ratio on growth performance, tissue fatty acid profile and histological alterations in the liver of juvenile Tor tambroides. Iran. J. Fish. Sci., 13: 185-200.
RAMEZANI-FARD, E; KAMARUDIN, M Sl HARMIN, S A and SAAD, C R (2012a). Dietary lipid levels affect growth and fatty acid profiles of Malaysian mahseer, Tor tambroides. N. Am. J. Aquacult., 74: 530-536.

RAMEZANI-FARD, E; KAMARUDIN, M S; HARMIN, S A and SAAD, C R (2012b). Dietary saturated and omega-3 fatty acids affect growth and fatty acid profiles of Malaysian mahseer. Eur. J. Lipid Sci. Technol., 114: 185-193.

RUYTER, B; MOYA-FALCÓN, C; ROSENLUND, $G$ and VEGUSDAL, A (2006). Fat content and morphology of liver and intestine of Atlantic salmon (Salmo salar): effects of temperature and dietary soybean oil. Aquaculture, 252: 441-452.

SMITH, D M; HUNTER, B J; ALLAN, G L; ROBERTS, D C K; BOOTH, M A and GLENCROSS, B D (2004). Essential fatty acids in the diet of silver perch (Bidyanus bidyanus): effect of linolenic and linoleic acid on growth and survival. Aquaculture, 236: 377-390.

TAN, X; LUO, Z; XIE, P and LIU, X (2009). Effect of dietary linolenic acid/linoleic acid ratio on growth performance, hepatic fatty acid profiles and intermediary metabolism of juvenile yellow catfish Pelteobagrus fulvidraco. Aquaculture, 296: 96-101.

TANAMATI, A; STEVANATO, F B; VISENTAINER, J E L; MATSUSHITA, M; DE SOUZA, N E and VISENTAINER, J V (2009). Fatty acid composition in wild and cultivated pacu and pintado fish. Eur. J. Lipid Sci. Technol., 111: 183-187.

TIAN, L X; LIU, Y J; YANG, H J; LIANG, G Y and NIU, J (2012). Effects of different dietary wheat starch levels on growth, feed efficiency and digestibility in grass carp (Ctenopharyngodon idella). Aquacult. Int., 20: 283-293.

TOCHER, D R (2003). Metabolism and functions of lipids and fatty acids in teleost fish. Rev. Fish. Sci., 11: 107-184.

TURCHINI, G M; FRANCIS, D S and DE SILVA, S S (2006). Fatty acid metabolism in the freshwater fish Murray cod (Macculochella peelii peelii) deduced by the whole-body fatty acid balance method. Comp. Biochem. Physiol. B. Biochem. Mol. Biol., 144: 110-118.

TURCHINI, M; WING-KEONG, N and TOCHER, D (2011b). Fish Oil Replacement and Alternative Lipid Sources in Aquaculture Feeds. Boca Raton, CRC Press.

VAMECQ, J; VALLEE, L; DE LA PORTE, P Ll FONTAINE, Ml DE CREAMER, DI VAN DEN 
BRANDEN, C and NALBONE, G (1993). Effect of various $n-3 / n-6$ fatty acid ratio contents of high fat diets on rat liver and heart peroxisomal and mitochondrial $\beta$-oxidation. BBA-Lipid Lipid Met., 1170: 151-156.

VIEGAS, E M M and CONTRERAS, E S G (1994). Effect of dietary crude palm oil and a deodorization distillate of soybean oil on growth of tambaqui (Colossoma macropomum) fingerlings. Aquaculture, 124: 128

WANG, Y; LIU, Y J; TIAN, L X; DU, Z Y; WANG, J T; WANG, S and XIAO, W P (2005). Effects of dietary carbohydrate level on growth and body composition of juvenile tilapia, Oreochromis niloticus $\times$ O. aureus. Aquacult. Res., 36: 1408-1413.

YOUNG, F V K (1987). Refining and fractionation of palm oil. Palm Oil: Critical Reports on Applied Chemistry (Gunstone, F D ed.). John Wiley and Sons, New York.

YU-ZHE, H; TONG-JUN, R; ZHI-QUIANG, J; BAIQIAO, J; JIAN, G; SHUNSUKE, K and CONNIE-FAY, K (2012). Effects of palm oil blended with oxidized fish oil on growth performances, haematology, and several immune parameters in juvenile Japanese sea bass, Lateolabrax japonicas. Fish Physiol. Biochem., 38: 1785-1794. 